\title{
MERGINŲ ŽINIOS APIE SOLIARIUME SKLEIDŽIAMOS ULTRAVIOLETINĖS SPINDULIUOTĖS POVEIKI SVEIKATAI BEI DEGINIMOSI ELGSENA
}

\author{
Jolita Kirvaitienè $\dot{1}^{1,2}$, Žaneta Maželienè $\dot{1}^{1,3}$, Diana Barragan Ferrer ${ }^{1}$, Albina Vaičiulevičiene் ${ }^{1}$ \\ ${ }^{1}$ Kauno kolegijos Medicinos fakultetas, ${ }^{2}$ Lietuvos sveikatos moksly universiteto \\ Medicinos akademija, ${ }^{3}$ Lietuvos sveikatos moksly universiteto Veterinarijos akademija
}

Raktažodžiai: ultravioletinè spinduliuotè, deginimosi elgsena, informuotumas.

\begin{abstract}
Santrauka
Pasaulio sveikatos organizacijos (PSO) duomenimis, pasaulyje kasmet nustatoma apie 132000 piktybinès melanomos atvejų, o atliktų mokslinių tyrimų, susijusių su dirbtinès ultravioletinès spinduliuotès (UV) poveikiu sveikatai, išvados priskyre ultravioletinių spindulių šaltinius prie didžiausios vėžio pavojaus kategorijos kartu su alkoholiu, cigaretemis ir asbestu. Neatsakinga elgsena naudojantis soliariumų teikiamomis paslaugomis jauname amžiuje gali sąlygoti odos nudegimus, priešlaikini odos senèjimą, akių pažeidimus, imuninès sistemos susilpnèjimą, odos ir akių melanomą, o informuotumas apie ultravioletinès spinduliuotès poveikị sveikatai susijęs su saugia jaunų merginų deginimosi soliariume elgsena, todèl mūsų tyrimo tikslas - įvertinti Kauno kolegijos Medicinos fakulteto merginų žinias apie ultravioletinès spinduliuotès poveikị sveikatai ir deginimosi soliariume elgseną. Anketinèje apklausoje dalyvavo 562 Kauno kolegijos Medicinos fakulteto studentès. Analizuojant apklausos duomenis nustatyta, kad soliariumo paslaugomis bent kartą per mènesị ir dažniau naudojosi ketvirtadalis Kauno kolegijos Medicinos fakulteto merginų, gyvenančių bei besimokančių didmiestyje, didžiosios dalies respondenčių deginimosi soliariume vieno seanso trukmè - vidutiniškai iki 10 min. Dažniau deginosi ir naudojosi soliariumo siūlomomis akcijomis ir abonentais merginos, pradejusios soliariumų paslaugomis naudotis iki 18 metų amžiaus. Dauguma respondenčių žinojo, kad soliariume skleidžiama ultravioletiné spinduliuotè veikia jų sveikatą. Naudojimasis so-
\end{abstract}

liariumų teikiamos nuolaidomis bei akcijomis buvo susijęs su įvaizdžiu. Vèliau pradejusių naudotis soliariumų teikiamomis paslaugomis merginų elgsena buvo saugesnè: jos dažniau rinkosi deginimosi trukmę atsižvelgiant ị odos tipą, jautrumą, soliariumo gamintojo rekomendacijas ir dažniau dengè randus, tatuiruotas kūno vietas. Dauguma merginų, kurios stengèsi laikytis deginimosi soliariume taisyklių (rekomendacijų), deginantis dejjosi apsauginius akinius, pažymètus CE ženklu.

\section{İvadas}

Vadovaujantis Lietuvos vėžio registro duomenimis, 1979 m. Lietuvoje buvo užregistruoti 705 odos vėžio atvejai, 2002 m. - 1900 atvejai, o 2011 m. apie 3000 odos véžio atvejų, iš jų 351 nauji odos melanomos atvejai, kurie dažniau diagnozuojami moterims nei vyrams, pacientes sparčiai jaunejja $[1,2]$. Odos piktybinių navikų rizikos veiksniais laikomi: melanomos atvejai šeimoje, vyresnis amžius, nustatytas I ir II odos tipas, didelis apgamų skaičius ir netipiniai apgamai, moteriška lytis, o melanomos atveju svarbu kaupiamasis (kumuliacinis) UV poveikis odai, UV spindulių sukelti nudegimai su pūslèmis, intensyvi, nuolat pasikartojanti UV spinduliuote [3-5]. Daugelis atliktų mokslinių tyrimu patvirtina, kad apie 75 proc. visos UV spindulių dozès žmonès gauna iki 20 metų bei susirgimų riziką didina bendras gautas asmens UV spindulių poveikis per gyvenimą. Taip pat nustatyta, kad ketvirtadalis žmogaus sukaupto kumuliacinio UV spindulių poveikio gali susikaupti iki 18 metų [6,7].

Soliariumų paslaugos Lietuvoje kasmet tampa populiaresnès. Jomis naudojasi apie 30 proc. jaunų žmonių, todèl natūralu, kad daugejja ir šias paslaugas teikiančiujų. Be to, keičiasi ir soliariumų lankymo priklausomai nuo metų laiko, intensyvumas, buvusios populiarios dažniau šaltuoju 
metų laiku, kai trūksta šilumos ir saulès, pastaraisiais metais neaplenkia pavasario bei vasaros sezonų. Norvegijoje, Austrijoje atliktų tyrimų duomenimis, dažniau soliariumo paslaugomos naudojasi jaunesnio amžiaus žmonès, merginos dažniau nei vaikinai bei naudojimasis soliariumų paslaugomis mažeja su amžiumi $[8,9]$. Vokietijoje keturi iš dešimties 14-45 metų amžiaus žmonių yra kada nors naudojęsi soliariumo paslaugomis $[8,10]$. Danijoje ši paslauga paplitusi tarp 15-34 metų žmonių, net 38 proc. 14-18 metų mokyklinio amžiaus vaikų per pastaruosius 12 mènesių lankèsi soliariume [13]. JAV, Švedijoje atliktuose tyrimuose nustatyta, kad jaunesniems nei 30 metu asmenims, soliariume apsilankantiems daugiau nei 10 kartų per metus, melanomos išsivystymo rizika padideja daugiau nei aštuonis kartus [14].

Moksliniais tyrimais įrodyta, kad neatsakingas elgesys naudojantis soliariumų paslaugomis jauname amžiuje gali sąlygoti odos nudegimus, priešlaikinị odos senèjimą, akių pažeidimus, imuninès sistemos susilpnejimą, odos ir akių melanomą, o informuotumas apie ultravioletinès spinduliuotès poveikị sveikatai formuoja saugią deginimosi soliariume elgseną $[11,12,16]$.

PSO Europos odos vėžio prevencijos bendrija (EUROSKIN), Tarptautinè apsaugos nuo nejonizuojančios spinduliuotès komisija (ICNIRP) nerekomenduoja: soliariumu naudotis jaunesniems nei $18 \mathrm{~m}$. asmenims; deginantis naudoti ịdegị skatinančius kosmetikos gaminius; degintis sergantiems, vartojantiems antibiotikus, hormoninius preparatus, psichotropines ir šlapimą varančias medžiagas, iš karto po pirties ar baseino, reklamuojant soliariumų paslaugas. Draudžiama ị soliariumus eiti nëščiosioms, tiems, kurių oda labai šviesi ir turintiems didesni nei $1 \mathrm{~cm}$ skersmens apgamą arba daug mažų apgamų. Nepaisant mokslininkų nuomonès, soliariume skleidžiamos ultravioletinès spinduliuotès poveikis žmogaus sveikatai vertinamas prieštaringai, bet vienareikšmiškai visi sutinka, kad teikiamos paslaugos turi būti kokybiškos ir ne jaunesniems asmenims nei 18 metų amžiaus $[17,18]$. Teikiantys soliariumų paslaugas teigia, kad soliariumuose galima išvengti pavojingo ultravioletinio spinduliuotès poveikio sveikatai valdant UV spindulių dozę, taip pat žinomas spinduliuojamų bangų pastovumas ir ilgiai, naudojami prižiūrimi, specialūs filtrai, kurie apsaugo odą nuo neigiamo UV spindulių poveikio, soliariume gaunama mažiau biologiškai kenksmingų UVB spindulių, skirtingai nei deginantis saulèje [19].

Tačiau Vakarų visuomenèse ịsitvirtinęs jaunų žmonių „grožio standarto“ suvokimas, kad įdegusi oda yra svarbus „grožio“ elementas bei žinių apie ultravioletinès spinduliuotès poveikį sveikatai stoka formuoja nesaugią deginimosi soliariume elgseną, kuri gali paskatinti nepageidau- jamas organizmo reakcijas: odos bèrimus, paraudimus bei didesnius sveikatos sutrikimus. Vokietijoje, Anglijoje atlikti tyrimai patvirtino, kad ,grožio standartų“ laikymasis yra svarbus motyvacinis veiksnys[10, 20]. Analizuojant Lenkijoje studijuojančių kosmetologijos ir medicinos studijų programose studentų žinias, nustatyta, kad nepaisant geresnių kosmetologijos studentų žinių, jų elgsena susijusi su deginimusi soliariume buvo rizikingesnè nei medicinos studentų [21].

Siekiant sumažinti rizikingos elgsenos paplitimą Jungtinejje Karalysteje, Danijoje, Šiaurès Airijoje, Prancūzijoje buvo vykdomos intervencinès profilaktinès programos mokymo įstaigose, kurių metu buvo platinama informacija apie galimą UV spindulių kenksmingą poveikị organizmui bei saugų naudojimąsi soliariumų paslaugomis. Šių programų efektyvumą patvirtino mažejantys soliariumų paslaugų vartotojų skaičius iki 18 metų amžiaus [22-25].

Tyrimo tikslas - ịvertinti Kauno kolegijos Medicinos fakulteto merginų žinias apie ultravioletinès spinduliuotès poveikị sveikatai ir deginimosi soliariume elgseną.

\section{Kontingentas ir tyrimo metodai}

Siekiant nustatyti Kauno kolegijos Medicinos fakulteto studenčių žinių apie ultravioletinès spinduliuotès poveikị sveikatai sąsajas su jų deginimosi soliariume elgsena 2014 $\mathrm{m}$. atlikta anketinė apklausa. Tiriamają grupę sudare 580 Kauno kolegijos visų trijų kursų studentès. Anketinès apklausos metu buvo išdalinta 580 anketų, grąžintos 562, atsako dažnis 96,6 proc. Apklausos instrumente - anketoje pateikti uždaro ir atviro tipo klausimai siekiant išsiaiškinti respondenčių žinias apie UV poveikị sveikatai ir įvertinti deginimosi soliariume priežastis bei ịpročius. Anketa sudaryta grupuojant klausimus. Bendra informacija: amžius, gyvenamoji vieta iki studijų; odos tipas; elgsena, susijusi su deginimusi soliariume, žinios apie soliariume skleidžiamos UV poveikị žmogaus organizmui.

Statistine duomenų analize buvo atlikta naudojant statistini programų paketą SPSS 20.0 apskaičiuojant procentinius duomenų ịverčius. Kintamujjų (tiriamujų požymių) kaupimui buvo naudojamas programų paketas Microsoft Office MS Excel. Kokybinių požymių statistinis ryšys tirtas taikant chi kvadrato $\left(\chi^{2}\right)$ kriterijų. Statistinių hipotezių reikšmingumui įvertinti pasirinktas reikšmingumo lygmuo $\mathrm{p}<0,05$.

\section{Rezultatai ir jų aptarimas}

Analizuojant Kauno kolegijos Medicinos fakulteto merginų anketinès apklausos duomenis, nustatyta, kad soliariumo paslaugomis bent kartą per mènesị ir dažniau naudojasi ketvirtadalis apklausoje dalyvavusių respondenčių, 
gyvenančių bei besimokančių didmiestyje, didžiosios dalies $(90,6$ proc.) respondenčiu deginimosi soliariume vieno seanso trukmè - vidutiniškai iki 10 min.

Studentès, kurios atsakè, kad pirmą kartą pasinaudojo soliariumo paslaugomis iki 18 metų amžiaus, 1,6 karto dažniau soliariume deginasi kartą per mènesį nei merginos, soliariumu paslaugomis pradejjusios naudotis 18 ir daugiau metų amžiaus (atitinkamai 26,1 proc. ir 16,2 proc., $\mathrm{p}<0,005)$. Studenčių deginimosi dažnis atsižvelgiant ị tai, kada jos pirmą kartą pasinaudojo soliariumo paslaugomis, parodytas 1 lentelèje.

Taip pat studentės, kurios teigè, kad pirmą kartą pasinaudojo soliariumo paslaugomis iki 18 metų amžiaus 3 kartus dažniau nei merginos, soliariumų paslaugomis pra-

1 lentelè. Studenčių deginimosi dažnis atsižvelgiant ị tai, kada jos pirmą kartą pasinaudojo soliariumo paslaugomis

$\chi^{2}$ - chi - kvadrato kriterijus; lls - laisvés laipsniu skaičius; $p$ - reikšmingumas

\begin{tabular}{|c|c|c|c|c|c|}
\hline \multirow{3}{*}{$\begin{array}{l}\text { Pirmą kartą pasi- } \\
\text { naudojusių soliariu- } \\
\text { mo paslaugomis res- } \\
\text { pondenčių amžius }\end{array}$} & \multicolumn{4}{|c|}{ Deginuosi kartą per mėnesị } & \multirow{3}{*}{$\begin{array}{c}\text { Reikš- } \\
\text { mingu- } \\
\text { mas }\end{array}$} \\
\hline & \multicolumn{2}{|c|}{$\mathrm{Ne}$} & \multicolumn{2}{|c|}{ Taip } & \\
\hline & $\mathbf{N}$ & Proc. & $\mathbf{N}$ & Proc. & \\
\hline 18 ir daugiau metų & 57 & 83,8 & 11 & 16,2 & \multirow{2}{*}{$\begin{array}{c}\chi^{2}=4,357 \\
11 s=1 \\
p=0,037\end{array}$} \\
\hline Iki 18 metų & 365 & 73,9 & 129 & 26,1 & \\
\hline
\end{tabular}

2 lentelė. Studenčių naudojimosi soliariumo siūlomomis akcijomis dažnis atsižvelgiant ị tai, kada jos pirmą kartą pasinaudojo soliariumo paslaugomis

$\chi^{2}$ - chi - kvadrato kriterijus; lls - laisvès laipsniu skaičius; $p$ - reikšmingumas

\begin{tabular}{|c|c|c|c|c|c|}
\hline \multirow{3}{*}{$\begin{array}{l}\text { Pirmą kartą pa- } \\
\text { sinaudojusių soli- } \\
\text { ariumo paslaugo- } \\
\text { mis respondenčių } \\
\text { amžius }\end{array}$} & \multicolumn{4}{|c|}{$\begin{array}{l}\text { Naudojuosi soliariume } \\
\text { teikiamomis akcijomis }\end{array}$} & \multirow{3}{*}{$\begin{array}{c}\text { Reikš- } \\
\text { mingu- } \\
\text { mas }\end{array}$} \\
\hline & \multicolumn{2}{|c|}{$\mathrm{Ne}$} & \multicolumn{2}{|c|}{ Taip } & \\
\hline & $\mathbf{N}$ & Proc. & $\mathbf{N}$ & Proc. & \\
\hline 18 ir daugiau metų & 168 & 89,8 & 19 & 10,2 & \multirow{2}{*}{$\begin{array}{c}\chi^{2}=26,519 \\
\mathrm{lls}=1 \\
\mathrm{p}=\mathbf{0 , 0 0 1}\end{array}$} \\
\hline Iki 18 metų & 264 & 70,4 & 111 & 29,6 & \\
\hline
\end{tabular}

3 lentelè. Studenčių naudojimosi soliariumo siūlomais įsigyti abonentais dažnis atsižvelgiant ị tai, kada jos pirmą kartą pasinaudojo soliariumo paslaugomis

$\chi^{2}$ - chi - kvadrato kriterijus; lls - laisvès laipsniu skaičius; $p$ - reikšmingumas

\begin{tabular}{|c|c|c|c|c|c|}
\hline \multirow{3}{*}{$\begin{array}{l}\text { Pirmą kartą pa- } \\
\text { sinaudojusių soli- } \\
\text { ariumo paslaugo- } \\
\text { mis respondenčių } \\
\text { amžius }\end{array}$} & \multicolumn{4}{|c|}{$\begin{array}{c}\text { Naudojuosi soliariume } \\
\text { siūlomais įsigyti abonen- } \\
\text { tais }\end{array}$} & \multirow{3}{*}{$\begin{array}{l}\text { Reikš- } \\
\text { mingu- } \\
\text { mas }\end{array}$} \\
\hline & \multicolumn{2}{|c|}{$\mathrm{Ne}$} & \multicolumn{2}{|c|}{ Taip } & \\
\hline & $\mathbf{N}$ & Proc. & $\mathbf{N}$ & Proc. & \\
\hline 18 ir daugiau metų & 166 & 88,8 & 21 & 11,2 & \multirow{2}{*}{$\begin{array}{c}\chi^{2}=17,599 \\
11 s=1 \\
p=0,001\end{array}$} \\
\hline Iki 18 metų & 275 & 73,3 & 111 & 26,7 & \\
\hline
\end{tabular}

dèjusios naudotis 18 ir daugiau metų amžiaus, naudojosi soliariumo siūlomomis akcijomis (atitinkamai 29,6 proc. ir 10,2 proc., $\mathrm{p}<0,005$ ) ir abonentais (atitinkamai 26,7 proc. ir 11,2 proc., $\mathrm{p}<0,005)$. Studenčių naudojimosi soliariumo siūlomomis akcijomis ir abonentais dažnis atsižvelgiant $i$ tai, kada jos pirmą kartą pasinaudojo soliariumo paslaugomis, parodytas 2 ir 3 lentelèse.

Analizuojant merginų žinias apie soliariume skleidžiamos ultravioletinès spinduliuotès poveikị sveikatai, nustatyta, kad dauguma merginų žino, kad soliariume skleidžiama ultravioletinė spinduliuotė veikia jų sveikatą. Taip pat merginų, turinčių I - II odos tipą žinios apie soliariume skleidžiamos ultravioletinès spinduliuotès poveikị sveikatai yra geresnès nei III - IV odos tipą turinčių merginų: daugiau I - II odos nei III - IV odos tipą turinčių respondenčių (atitinkamai 86,6 proc. ir 78,$4 ; \mathrm{p}<0,05$ ) teisingai teigè, $\mathrm{kad}$ šie spinduliai kenksmingi sveikatai, pritarè, kad soliariumo idegis nepalaiko geros odos būklès (atitinkamai 70,9 proc. ir 58,9; $<<0,05$ ), gali sukelti véži (atitinkamai 91,2 proc. ir 76,3; $<<0,05)$, skatina odos pakitimus, pvz., raukšles ar senejjimą (atitinkamai 89,6 proc. ir 78,4; $\mathrm{p}<0,05$ ). Merginų žinios apie soliariume skleidžiamos ultravioletinès spinduliuotès poveikị sveikatai atsižvelgiant ị odos tipą pateiktos 4 lentelèje.

Dažniausios deginimosi soliariume priežastys yra susijusios su susiformavusiais „grožio“ standartais bei ịvaizdžiu: beveik pusė apklausoje dalyvavusių merginų, kurios naudojosi soliariumo paslaugomis, mané, kad įdegusi oda atrodo madingai $(49,8)$, teigè, kad drovisi baltos odos spalvos $(51,2$ proc.), įdegusi oda atrodo gražiau $(49,4)$, jauniau $(47,4)$ bei patraukliau, seksualiau $(50,7)$. Analizuojant merginų deginimosi soliariume elgseną nustatyta, kad naudojimasis soliariumų teikiamos nuolaidomis bei akcijomis taip pat yra susijęs su įvaizdžiu.

Dažniau naudojasi soliariumų teikiamomis nuolaidomis bei akcijomis ir deginasi respondentès, kurioms svarbu nei tos, kurioms nèra svarbu atrodyti patraukliau (atitinkamai 66,9 ir 25,6 proc. $p<0,05$ ). Taip pat tos, kurios mano, kad idegis apsaugo nuo intensyvių saulès spindulių, skirtingai negu nemanančios (atitinkamai 14,9 ir 3,2 proc. $\mathrm{p}<0,05$ ). Merginų, kurios naudojasi soliariumų teikiamomis nuolaidomis bei akcijomis pasiskirstymas atsižvelgiant i deginimosi priežastis - 5 lentelèje.

Analizuojant Kauno kolegijos Medicinos fakulteto merginų anketinès apklausos duomenis, nustatyta, kad respondenčių, vèliau pradejusių naudotis soliariumų teikiamomis paslaugomis, elgsena yra saugesnè: studentès, kurios atsakè, kad pirmą kartą pasinaudojo soliariumo paslaugomis 18 ir daugiau metų amžiaus, dažniau pasirinko deginimosi trukmę atsižvelgiant ị odos tipą, jautrumą, so- 
4 lentelè. Merginų žinios apie soliariume skleidžiamos ultravioletinès spinduliuotès poveikị sveikatai atsižvelgiant ị odos tipą $\chi^{2}$ - chi - kvadrato kriterijus; lls - laisvès laipsniu skaičius; $p$ - reikšmingumas

\begin{tabular}{|c|c|c|c|c|c|c|}
\hline \multirow{2}{*}{$\begin{array}{l}\text { Teiginiai apie } \\
\text { soliariume } \\
\text { skleidžiamą } \\
\text { ultravioletinę } \\
\text { spinduliuotę }\end{array}$} & \multirow[t]{2}{*}{$\begin{array}{l}\text { Odos } \\
\text { tipai }\end{array}$} & & \multicolumn{3}{|c|}{$\begin{array}{c}\text { Pritariu apie soliariume } \\
\text { skleidžiamos ultravioleti- } \\
\text { nės spinduliuotės poveikị } \\
\text { sveikatai }\end{array}$} & \multirow[t]{2}{*}{$\begin{array}{l}\text { Reikšmin- } \\
\text { gumas }\end{array}$} \\
\hline & & & Taip & $\mathrm{Ne}$ & $\begin{array}{c}\text { Neturiu } \\
\text { nuomonès }\end{array}$ & \\
\hline \multirow{4}{*}{$\begin{array}{l}\text { Šie spinduliai } \\
\text { nekenksmingi } \\
\text { sveikatai }\end{array}$} & \multirow{2}{*}{ I-II } & $\mathrm{N}$ & 12 & 158 & 12 & \multirow{4}{*}{$\begin{array}{c}\chi^{2}=7,525 \\
11 s=2 \\
p=0,023\end{array}$} \\
\hline & & Proc. & 6,6 & 86,8 & 6,6 & \\
\hline & \multirow{2}{*}{ III-IV } & $\mathrm{N}$ & 27 & 298 & 55 & \\
\hline & & Proc. & 7,1 & 78,4 & 14,5 & \\
\hline \multirow{5}{*}{$\begin{array}{l}\text { Soliariumo ịde- } \\
\text { gis palaiko gerą } \\
\text { odos būklę }\end{array}$} & & & & & & \\
\hline & \multirow{2}{*}{ I-II } & $\mathrm{N}$ & 20 & 129 & 33 & \multirow{4}{*}{$\begin{array}{c}\chi^{2}=7,550 \\
11 \mathrm{~s}=2 \\
\mathrm{p}=0,023\end{array}$} \\
\hline & & Proc. & 11,0 & 70,9 & 18,1 & \\
\hline & \multirow{2}{*}{ III-IV } & $\mathrm{N}$ & 56 & 224 & 100 & \\
\hline & & Proc. & 14,7 & 58,9 & 26,3 & \\
\hline \multirow{4}{*}{ Gali sukelti vèžị } & \multirow{2}{*}{ I-II } & $N_{1}$ & 166 & 4 & 12 & \multirow{4}{*}{$\begin{array}{c}\chi^{2}=17,957 \\
11 s=2 \\
p=0,0001\end{array}$} \\
\hline & & Proc. & 91,2 & 2,2 & 6,6 & \\
\hline & \multirow{2}{*}{ III-IV } & $\mathrm{N}$ & 289 & 24 & 66 & \\
\hline & & Proc. & 76,3 & 6,3 & 17,4 & \\
\hline \multirow{4}{*}{$\begin{array}{l}\text { Skatina odos } \\
\text { pakitimus, pvz. } \\
\text { raukšles ar se- } \\
\text { néjimą }\end{array}$} & \multirow[b]{2}{*}{ I-II } & $\mathrm{N}$ & 163 & 7 & 12 & \multirow{4}{*}{$\begin{array}{c}\chi^{2}=11,900 \\
11 s=2 \\
p=0,003\end{array}$} \\
\hline & & Proc. & 89,6 & 3,8 & 6,6 & \\
\hline & \multirow{2}{*}{ III-IV } & $\mathrm{N}$ & 298 & 17 & 65 & \\
\hline & & Proc. & 78,4 & 4,5 & 17,1 & \\
\hline
\end{tabular}

5 lentelè. Merginų, kurios naudojasi soliariumų teikiamomis nuolaidomis bei akcijomis pasiskirstymas atsižvelgiant ị deginimosi priežastis

$\chi^{2}$ - chi - kvadrato kriterijus; lls - laisvés laipsniu skaičius; $p$ - reikšmingumas

\begin{tabular}{|c|c|c|c|c|c|}
\hline \multirow{2}{*}{\multicolumn{3}{|c|}{ Priežastys }} & \multicolumn{2}{|c|}{$\begin{array}{l}\text { Naudojuosi } \\
\text { akcijomis, } \\
\text { nuolaidomis }\end{array}$} & \multirow[t]{2}{*}{$\begin{array}{l}\text { Reikšmin- } \\
\text { gumas }\end{array}$} \\
\hline & & & $\mathrm{Ne}$ & Taip & \\
\hline \multirow{4}{*}{$\begin{array}{l}\text { Soliariumuose } \\
\text { lankausi, nes } \\
\text { noriu atrodyti } \\
\text { patraukliau }\end{array}$} & \multirow{2}{*}{$\mathrm{Ne}$} & $\mathrm{N}$ & 328 & 113 & \multirow{4}{*}{$\begin{array}{c}\chi^{2}=69,043 \\
11 s=1 \\
p=0,001\end{array}$} \\
\hline & & Proc. & 74,4 & 25,6 & \\
\hline & \multirow{2}{*}{ Taip } & $\mathrm{N}$ & 41 & 80 & \\
\hline & & Proc. & 33,9 & 66,1 & \\
\hline \multirow{4}{*}{$\begin{array}{l}\text { Manau įdegis } \\
\text { apsaugo nuo } \\
\text { intensyvių } \\
\text { saulès spin- } \\
\text { dulių }\end{array}$} & \multirow{2}{*}{$\mathrm{Ne}$} & $\mathrm{N}$ & 427 & 14 & \multirow{4}{*}{$\begin{array}{c}\chi^{2}=24,211 \\
11 s=1 \\
p=0,001\end{array}$} \\
\hline & & Proc. & 96,8 & 3,2 & \\
\hline & \multirow[b]{2}{*}{ Taip } & $\mathrm{N}$ & 103 & 18 & \\
\hline & & Proc. & 85,1 & 14,9 & \\
\hline
\end{tabular}

liariumo gamintojo rekomenduojamą deginimosi trukmę nei merginos, soliariumų paslaugomis pradejusios naudotis iki 18 metų amžiaus (atitinkamai 37,9 proc. ir 23,5 proc., $\mathrm{p}<0,005)$. Taip pat dažniau soliariume dengè randus, tatuiruotas kūno vietas (atitinkamai 12,8 proc. ir 5,9 proc., $\mathrm{p}<0,005)$. Studenčių deginimosi elgsena atsižvelgiant ị tai, kada jos pirmą kartą pasinaudojo soliariumo paslaugomis, pateikiama 6 ir 7 lentelèse.
6 lentelè. Studenčių deginimosi soliariume trukmės pasirinkimas atsižvelgiant ị tai, kada jos pirmą kartą pasinaudojo soliariumo paslaugomis

$\chi^{2}$ - chi - kvadrato kriterijus; lls - laisvès laipsniu skaičius; $p$-reikšmingumas

\begin{tabular}{|c|c|c|c|c|c|}
\hline \multirow{3}{*}{$\begin{array}{l}\text { Pirmą kartą pa- } \\
\text { sinaudojusių soli- } \\
\text { ariumo paslaugo- } \\
\text { mis respondenčių } \\
\text { amžius }\end{array}$} & \multicolumn{4}{|c|}{$\begin{array}{l}\text { Deginimosi trukmę pasiren- } \\
\text { ku atsižvelgiant į odos tipą, } \\
\text { odos jautrumą, soliariumo } \\
\text { gamintojo rekomenduoja- } \\
\text { mą deginimosi trukmę }\end{array}$} & \multirow[t]{3}{*}{$\begin{array}{c}\text { Reikš- } \\
\text { mingu- } \\
\text { mas }\end{array}$} \\
\hline & \multicolumn{2}{|c|}{$\mathrm{Ne}$} & \multicolumn{2}{|c|}{ Taip } & \\
\hline & $\mathbf{N}$ & Proc. & $\mathbf{N}$ & Proc. & \\
\hline 18 ir daugiau metų & 233 & 62,1 & 142 & 37,9 & \multirow{2}{*}{$\begin{array}{c}\chi^{2}=11,584 \\
1 l s=1 \\
p=0,001\end{array}$} \\
\hline Iki 18 metų & 143 & 76,5 & 44 & 23,5 & \\
\hline
\end{tabular}

7 lentelè. Studenčių deginimosi elgsena atsižvelgiant ị tai, kada jos pirmą kartą pasinaudojo soliariumo paslaugomis $\chi^{2}$ - chi - kvadrato kriterijus; lls - laisvés laipsniu skaičius; $p$-reikšmingumas

\begin{tabular}{|c|c|c|c|c|c|}
\hline \multirow{3}{*}{$\begin{array}{l}\text { Pirmą kartą } \\
\text { pasinaudojusių } \\
\text { soliariumo paslau- } \\
\text { gomis respondenčių } \\
\text { amžius }\end{array}$} & \multicolumn{4}{|c|}{$\begin{array}{c}\text { Deginantis soliariume } \\
\text { dengiu randus, tatuiruo- } \\
\text { tas kūno vietas }\end{array}$} & \multirow{3}{*}{$\begin{array}{l}\text { Reikšmin- } \\
\text { gumas }\end{array}$} \\
\hline & \multicolumn{2}{|c|}{$\mathrm{Ne}$} & \multicolumn{2}{|c|}{ Taip } & \\
\hline & $\mathbf{N}$ & Proc. & $\mathbf{N}$ & Proc. & \\
\hline 18 ir daugiau metų & 327 & 87,2 & 48 & 12,8 & \multirow{2}{*}{$\begin{array}{c}\chi^{2}=6,355 \\
11 s=1 \\
p=0,012\end{array}$} \\
\hline Iki 18 metų & 176 & 94,1 & 11 & 5,9 & \\
\hline
\end{tabular}

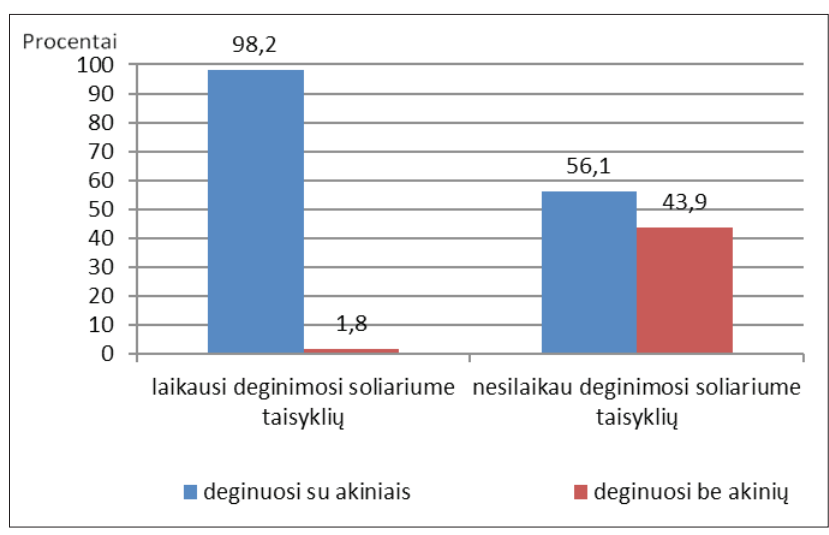

1 pav. Studenčių deginimosi soliariume taisyklių (rekomendacijų) laikymosi ir apsauginių akinių, kurie privalo būti pažymėti CE ženklu ir išduodami kiekvienam soliariumo lankytojui naudojimo sąsajos

$\chi^{2}=69,982, l l s=1, p=0,001$

Studenčių, deginimosi soliariume taisyklių (rekomendacijų) laikymosi ir apsauginių akinių, kurie privalo būti pažymèti CE ženklu ir išduodami kiekvienam soliariumo lankytojui naudojimo sąsajos pateiktos 1 paveiksle. Dauguma (98,2 proc.) merginų, kurios stengèsi laikytis deginimosi soliariume taisyklių (rekomendacijų), deginantis 
dejjosi apsauginius akinius, skirtingai nei tos, kurios rekomendacijų nesilaikè (56,1 proc.).

Apibendrinant gautus tyrimo rezultatus, soliariumo paslaugomis bent kartą per mènesị ir dažniau naudojasi ketvirtadalis merginų, gyvenančių bei besimokančių didmiestyje. Dauguma merginų žino, kad soliariume skleidžiama ultravioletinė spinduliuotè veikia jų sveikatą. Naudojimasis soliariumų teikiamomis paslaugomis susijęs su įvaizdžiu. Dažniau deginosi merginos, pradejjusios soliariumų paslaugomis naudotis iki 18 metu amžiaus, vèliau pradejjusių ir merginų, kurios stengèsi laikytis deginimosi soliariume rekomendacijų, deginimosi elgsena yra saugesnè.

Atsižvelgiant ị kitų Europos šalių gerają praktiką bei pasiektus rezultatus ir vertinant situaciją Lietuvoje, mokymo įstaigose taikant intervencines profilaktinès programas tikètina taip pat sulaukti teigiamų rezultatų.

\section{Išvados}

1. Soliariumo paslaugomis bent kartą per mènesị ir dažniau naudojasi ketvirtadalis Kauno kolegijos Medicinos fakulteto merginų, gyvenančių bei besimokančių didmiestyje, didžiosios dalies respondenčių deginimosi soliariume vieno seanso trukmè - vidutiniškai iki 10 min. Dažniau deginosi ir naudojosi soliariumo siūlomomis akcijomis ir abonentais merginos, pradejusios soliariumų paslaugomis naudotis iki 18 metų amžiaus.

2. Dauguma merginų žino, kad soliariume skleidžiama ultravioletinè spinduliuotė veikia jų sveikatą: merginų, turinčių I - II odos tipą, žinios apie soliariume skleidžiamos ultravioletinès spinduliuotès poveikị sveikatai yra geresnès nei III - IV odos tipą turinčių merginų. Jos dažniau teisingai teigè, kad šie spinduliai kenksmingi sveikatai, pritarè, kad soliariumo ịdegis nepalaiko geros odos būklès, gali sukelti vėžĭ, skatina odos pakitimus (pvz. raukšles ar senejjimą).

3. Naudojimasis soliariumų teikiamomis nuolaidomis bei akcijomis yra susijęs su ịvaizdžiu. Dažniau naudojasi soliariumų teikiamomis nuolaidomis bei akcijomis ir deginasi respondentès, kurioms svarbu atrodyti patraukliau nei tos, kurioms tai nèra svarbu. Taip pat tos, kurios mano, kad ịdegis apsaugo nuo intensyvių saulès spindulių.

4. Vèliau pradejjusių naudotis soliariumų teikiamomis paslaugomis merginų elgsena yra saugesnè: studentès, kurios atsakè, kad pirmą kartą pasinaudojo soliariumo paslaugomis 18 ir daugiau metų amžiaus, dažniau pasirinko deginimosi trukmę atsižvelgiant ị odos tipą, odos jautrumą, soliariumo gamintojo rekomenduojamą deginimosi trukmę ir dažniau deginantis soliariume dengè randus, tatuiruotas kūno vietas. Dauguma merginu, kurios stengèsi laikytis besidegdamos soliariume taisyklių (rekomendacijų), besidegindamos dejosi apsauginius akinius.

\section{Literatūra}

1. Smailytė G., Birutė A. ir kt. Vèžys Lietuvoje 2011 metais. Nacionalinis vėžio institutas, 2014;ISSN 2029-6274.

2. Dessinioti C, Tzannis K, Sypsa V, Nikolaou V, Kypreou K, Antoniou C, Katsambas A, Stratigos AJ. Epidemiologic risk factors of basal cell carcinoma development and age at onset in a Southern European population from Greece. Exp Dermatol 2011;20(8):622-6.

http://dx.doi.org/10.1111/j.1600-0625.2011.01275.x

3. Khosravi H, Schmidt B, Huang JT . Characteristics and outcomes of nonmelanoma skin cancer (NMSC) in children and young adults. J Am Acad Dermatol 2015;73(5):785-90.

http://dx.doi.org/10.1016/j.jaad.2015.08.007

4. Leiter U, Eigentler T, Garbe C. Epidemiology of skin cancer. Adv Exp Med Biol. 2014;810:120-40.

5. Castro C, Antunes L, Lunet N, Bento MJ. Cancer incidence predictions in the North of Portugal: keeping populationbased cancer registration up to date. Eur J Cancer Prev 2016;25(5):472-80.

http://dx.doi.org/10.1097/CEJ.0000000000000199

6. Vuong K, Armstrong BK, Weiderpass E, Lund E, Adami HO, Veierod MB , Barrett JH, Davies JR, Bishop DT, Whiteman DC, Olsen CM, Hopper JL, Mann GJ, Cust AE, McGeechan K. Australian Melanoma Family Study Investigators. Development and external validation of a melanoma risk prediction model based on self-assessed risk factors. JAMA Dermatol 2016;152(8):889-96.

http://dx.doi.org/10.1001/jamadermatol.2016.0939

7. Balk SJ. Council on environmental health; section on dermatology. Ultraviolet radiation: a hazard to children and adolescents. Pediatrics 2011;127(3):791-817.

http://dx.doi.org/10.1542/peds.2010-3502

8. Haluza D, Simic S, Moshammer H. Sunbed use prevalence and associated skin health habits: results of a representative, population-based survey among Austrian Residents. Int J Environ Res Public Health 2016;13(2):231.

http://dx.doi.org/10.3390/ijerph13020231

9. Moan JE, Baturaite Z, Grigalavicius M, Juzeniene A. Sunbed use and cutaneous melanoma in Norway. Scand J Public Health 2013;41(8):812-7.

http://dx.doi.org/10.1177/1403494813496601

10. Schneider S, Görig T, Breitbart EW, Greinert R, Diehl K. Prevalence, risk groups, and reasons for sunbed use in Germany. Hautarzt 2016;67(3):226-33.

http://dx.doi.org/10.1007/s00105-015-3753-3

11. Gavin A., Boyle R., Donnelly D. et al. Trends in skin cancer knowledge, sun protection practices and behaviours in the Northern Ireland population.European Journal of Public Health 2011;16: 1-5.

12. Boyle R, O'Hagan HA, Donnelly D, Donnelly C, Gordon S, McElwee S. et al. Trends in reported sun bed use, sunburn, and sun care knowledge and attitudes in a U.K. region: results of a 
survey of the Northern Ireland population. British Journal of Dermatology 2010;163:1269-1275.

http://dx.doi.org/10.1111/j.1365-2133.2010.09977.x

13. Bentzen J, Krarup AF, Castberg IM, Jensen PD, Philip A. Determinants of sunbed use in a population of Danish adolescents. Eur J Cancer Prev 2013;22(2):126-30. http://dx.doi.org/10.1097/CEJ.0b013e3283581934

14. Doré JF, Chignol MC. Tanning salons and skin cancer. Photochem Photobiol Sci 2012;11(1):30-7. http://dx.doi.org/10.1039/C1PP05186E

15. Dennis K L, Lowe B J, Snetselaar GL. Tanning behaviour among young frequent tanners is related to attitudes and not lack of knowledge about the dangers. Health Education Journal 2009;68(3):232-243. http://dx.doi.org/10.1177/0017896909345195

16. Stanganelli I, Naldi L, Falcini F, Magi S, Mazzoni L, Medri M, Bertoncini R, Calderoni O, Agnoletti V, Nadiani L, Palmieri G, Di Nuzzo S, Pagliarello C,Gandini S. Parental use and educational campaigns on sunbed use among teenagers and adolescents. Medicine (Baltimore) 2016; 95(11).

http://dx.doi.org/10.1097/MD.0000000000003034

17. Khazova M, O'Hagan JB, Robertson S. Survey of UV Emissions from Sunbeds in the UK. Photochem Photobiol 2015; 91(3):545-52.

http://dx.doi.org/10.1111/php.12425

18. Gavin A, Donnelly C, Devlin A, Devereux C. Public at risk: a survey of sunbed parlour operating practices in Northern Ireland. British Journal of Dermatology 2010; (162): 627-632. http://dx.doi.org/10.1111/j.1365-2133.2009.09591.x

19. Diffey BL, Osterwalder U, Herzog B. Suntanning with sunscreens: a comparison with sunbed tanning. Photodermatol Photoimmunol Photomed 2015;31(6):307-14.

http://dx.doi.org/10.1111/phpp. 12190

20. Lake JR, Thomson CS, Twelves CJ, Davies EA. A qualitative investigation of the motivations, experiences and views of female sunbed users under the age of 18 in England. J Public Health (Oxf) 2014;36(1):56-64. http://dx.doi.org/10.1093/pubmed/fds107

21. Zuba EB, Francuzik W, Malicki P, Osmola-Mańkowska A, Jenerowicz D. Knowledge about ultraviolet radiation hazards and tanning behavior of cosmetology and medical students. Acta Dermatovenerol Croat 2016;24(1):73-7.

22. Boyle R, O'Hagan AH, Donnelly D, Donnelly C, Gordon S, McElwee G, Gavin A.Trends in reported sun bed use, sunburn, and sun care knowledge and attitudes in a U.K. region: results of a survey of the Northern Ireland population. Br J Dermatol 2010;163(6):1269-75.

http://dx.doi.org/10.1111/j.1365-2133.2010.09977.x

23. Køster B, Thorgaard C, Philip A, Clemmensen H. Sunbed use and campaign initiatives in the Danish population, 20072009: a cross-sectional study. J Eur Acad Dermatol Venereol
2011;25(11):1351-5

http://dx.doi.org/10.1111/j.1468-3083.2010.03960.x

24. Grange F, Mortier L, Crine A, Robert C, Sassolas B, Lebbe C, Lhomel C, Saiag P. Prevalence of sunbed use, and characteristics and knowledge of sunbed users: results from the French population-based Edifice Melanoma survey. J Eur Acad Dermatol Venereol 2015;29:23-30.

http://dx.doi.org/10.1111/jdv.12899

25. Aarestrup C, Bonnesen CT, Thygesen LC, Krarup AF, Waagstein AB, Jensen PD, Bentzen J. The effect of a school-based intervention on sunbed use in Danish pupils at continuation schools: a cluster-randomized controlled trial. J Adolesc Health 2014;54(2):214-20

http://dx.doi.org/10.1016/j.jadohealth.2013.08.011

\section{GIRLS' KNOWLEDGE OF SOLARIUM EMITTED EXPOSURE TO ULTRAVIOLET RADIATION, TANNING AND HEALTH BEHAVIOUR J. Kirvaitienė, Ž. Maželienė, D. Barragan Ferrer,}

\section{A. Vaičiulevičienè}

Key words: ultraviolet radiation, tanning behavior, awareness. Summary

According to the data of the World Health Organization (WHO) in the world about 132000 malignant melanoma cases are set annually and research related to artificial ultraviolet radiation (UV) effects on health, the findings attributed to ultraviolet light sources to the highest cancer risk categories as in combination with alcohol, cigarettes and asbestos. Irresponsible behavior using tanning services at a young age can cause skin burns, premature skin ageing, eye damage, immune system weakening, skin and eye melanoma, and awareness of ultraviolet radiation health effects related to safety of young girls' tanning solarium behavior, so our study is to assess University of Applied Sciences Faculty of Medicine girls' understanding of ultraviolet radiation on health and the solarium tanning behavior. 562 of Kaunas college students of the Faculty of Medicine participated in a questionnaire. The analysis of the survey data showed that solarium services at least once a month and more frequently were used by a quarter of Kaunas University Faculty of Medicine of girls living and studying in a big city, for the majority of respondents tanning solarium duration of one session was an average of 10 minutes. More often girls used solarium shares offered and subscribed to the girls, started tanning services access to 18 years of age. Most of the respondents knew that the solarium emitted ultraviolet radiation on their health. Using solarium provided discounts and shares was mostly related to the image. Girls who started using tanning services later were safer: they more often chose the duration of the sun on theire skin type, sensitivity, solarium manufacturers' recommendations and often covered the scars and tattooed body. Most of the girls who tried to follow the tanning solarium rules (recommendations), pretended protective glasses CE-marked.

Correspondence to: zaneta.mazeliene@gmail.com

Gauta 2016-10-04 